sions from large-scale expansion of for-profit higher education. The United States has had to develop regulations to reconcile government provision of financial aid to students attending for-profit colleges and the dangers of poor quality provision by those institutions.

England should consider a more extensive program of government support for IAG in primary and early secondary school. Fateful student choices about higher education begin early as students, their parents, and their teachers make decisions about what fields they should prepare for in higher secondary school in order to be eligible for admission into selective universities. Also, students need to get high grades in the national examinations, usually taken at the age of 16 and again at 18 , in order to qualify for entry into these most selective universities.

English universities do engage in contextualized admissions but they could do more. The limited success of the most selective UK universities in diversifying themselves by class and race/ethnicity is rooted in part in their emphasis on only accepting highly prepared students defined in terms of the dominant cultural categories. English universities therefore may benefit from a reconsideration of what constitutes merit in university admission. Are there other ways of measuring ability to benefit from higher education that would open up new opportunities for students coming from underrepresented backgrounds? These questions have been subject to extensive debate in the United States in the context of affirmative action, and selective universities have developed a variety of alternative measures of academic merit.

Finally, as England continues its use of the Teaching Excellence Framework (TEF) to reward institutions for instructional quality, it will be important to carefully track the intended and unintended impacts of the TEF. This monitoring effort could benefit from research on the obstacles encountered and negative side effects produced by performance funding in the United States.

DOI: http://dx.doi.org/Io.6oI7/ihe.20I8.92.I0210

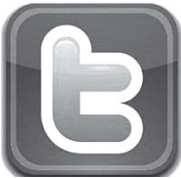

In addition to our Web site and Facebook page, we are now tweeting. We hope you will consider "following" us on Twitter!

\section{Anarchy and Exploitation in Scientific Communication}

\section{Philip G. Altbach}

Philip G. Altbach is research professor and founding director of the Center for International Higher Education, Boston College, US. E-mail: altbach@bc.edu.

(Note: This article also appears in Higher Education in Russia and Beyond.)

$\mathrm{T}$ echnology, greed, a lack of clear rules and norms, hypercompetitiveness, and a certain amount of corruption have resulted in confusion and anarchy in the world of scientific communication. Not too long ago, scientific publication was largely in the hands of university publishers and nonprofit scientific societies, most of which were controlled by the academic community. Academic conferences were sponsored by universities or disciplinary organizations of academics and scientists. Most of this was done on a nonprofit basis and largely controlled by small groups of respected professors at the main research universities, largely in North America and Western Europe. It was all quite "gentlemanly" and controlled by a male-dominated scientific elite.

Then multiple tsunamis hit the groves of academe. Perhaps the most important was the massification of postsecondary education - the tremendous expansion of enrollments and numbers of universities worldwide. Now, with close to 200 million students in more than 22,000 universities globally, the higher education enterprise is huge. And while only a small proportion of these universities produce much research or aspire to the status of research universities, their numbers are growing as more institutions are lured by the rankings, which mainly measure research productivity, and by the natural desire to join the academic elite. Governments, accreditors, and quality assurance agencies are also stressing research and publications, in part because these are among the few metrics that can be accurately measured. At the same time, the global knowledge economy pushed top universities to link to academe internationally and to compete with institutions worldwide.

As a result of this increased competition and pressure on universities and individual academics to "publish or perish," tremendous pressure was placed on the existing scientific communication system, which was eventually unable to cope with increasing demands. At the same time, the Internet created additional challenges to the system, as journals had to adapt to new ways of publishing articles, evaluating submissions, and other aspects of their work. What had been a cottage industry managed by scholars with little 
training in communication suddenly became a large industry. There are now more than I50,000 scientific journals, of which 64,000 claim to be peer reviewed.

\section{IMPLICATIONS}

First, major publishers and media companies, seeing that they could make a large profit from scientific journals, moved into the marketplace. Multinationals such as Springer and Elsevier are the giants, each now publishing more than a thousand journals in all fields. Journal subscription prices were increased to astronomical levels, with some journals costing $\$ 20,000$ or more. For example, Brain Research, published by Elsevier, costs \$24,000 for an annual subscription. These publishers mainly purchased existing journals from other publishers or scientific societies. They also started new journals in many interdisciplinary fields. The multinationals ended up with hundreds of journals, which they "packaged" for sale to libraries-which paid huge fees for access to all of the journals, as they were forced to purchase the entire list. In some scientific fields, submission fees for authors were imposed or raised. Journal publication became highly profitable. This system, of course, limited access to the latest scientific information to those who could pay for it.

Eventually, a reaction again journal prices by libraries and many academics led to the "open access" movement: some new journals were established with the goal of providing less expensive access to knowledge. The established multinational publishers responded by providing a kind of open access, mainly by charging authors for permission to provide their published articles less expensively to readers. By 2017 , continuing conflicts between academic libraries and the multinational publishers concerning the high cost of access to journals have not resulted in any consensus on how to solve these complex problems.

Universities are themselves publishers of many scientific journals. A number of prestigious universities presses, such as Chicago, Johns Hopkins, Oxford, and others have traditionally published high quality academic journalsand continue to do so. They have in general maintained reasonable prices and have successfully adapted to new technologies. It is also the case that many individual universities worldwide publish local journals that have little circulation or prestige. For example, most Chinese research universities publish journals in several fields that have little impact and do not attract authors outside of the institution. There seems to be little justification for such publicationsand they are likely to be damaged by the proliferation of low-quality "international” journals.

At the same time, the dramatic increase in the number of journals and the dramatic expansion in the number of pa- pers being submitted to journals have placed unsustainable strain on the traditional peer review system. The increase in submissions is due to the expansion of the academic profession, increased emphasis on "publish or perish," and the rapid advance of scientific innovation and knowledge in general. But it is increasingly difficult to find qualified peer reviewers or talented journal editors. These jobs, while very important, are generally very time consuming, uncompensated, and even anonymous, a pure contribution to science and scholarship.

Another frightening and widespread development in the scientific communication industry is the emergence of “academic fakery." On December 29, 2016, The New York Times devoted a long article to "Fake Academe, Looking a Lot Like the Real Thing." The article discussed the proliferation of fake conferences and fake journals. International "academic" conferences organized by shady companies in India and elsewhere charge participants high fees to attend meetings held in hotels around the world, and accept all papers submitted, regardless of quality. Academics are sufficiently desperate to be able to put on their CV that they have had a paper accepted for an international conference, that they pay for these useless events.

\section{Not too long ago, scientific publication was largely in the hands of university publishers and nonprofit scientific soci- eties.}

There is also a proliferation of fake journals. No one knows how many of these exist, but their number is in the hundreds or even thousands. Jeffrey Beall, an American university librarian, has been tracking these fakes for years, and now lists at least 923 publishers, many with multiple "journals," up from I8 in 20II. In late 20I6, Beall announced that he was no longer compiling his valuable list and it was removed from the Internet. Although he gave no explanation, there is little doubt that he was threatened with lawsuits. The fake journals are often published from Pakistan or Nigeria by invisible publishers and editors. They often claim to be peer reviewed and list internationally prominent academics on their editorial boards-people who seldom actually agreed to serve there and find it difficult to have their names removed when they request it. But almost all papers submitted tend to be published quickly once a fee, often substantial, is paid to the publisher. 


\section{What IS to Be Done?}

Without question, there is anarchy in the realm of knowledge communication in the twenty-first century. A combination of mass production of scientific papers, most of little scholarly value, tremendous pressure on academics to publish their work regardless of ethical considerations, the communications and publishing revolution made possible by the Internet, the greed of the established multinational publishers, and the huge new coterie of fake publishers have all combined to produce confusion. The issues involved are complex-how to manage technology, accommodate the expansion of scientific production, rationalize peer review, break the monopoly of the multinationals, and, of great importance, instill a sense of ethics and realistic expectations into the academic community itself. The implications of these changes for journals published in languages other than English and in countries other than the main publishing countries are also unclear. It is likely they will be weakened by these global trends. Questions abound, answers are few.

DOI: http://dx.doi.org/Io.6oI7/ihe.20I8.92.9786

\section{Globalizing the Academic Presidency: Competing for Talented Leadership}

\section{RICHARD A. SKIN NER}

Richard A. Skinner is senior consultant, Harris Search Associates, and served as president of Royal Roads University in Canada and Clayton State University in the United States. E-mail: rick@harrisandassociates.com.

Tigher education is not immune to globalization. Rare 1 today is the research-intensive university that does not promote and support students and professors spending time abroad and, while still modest in number, foreignborn and/or -educated presidents are increasingly selected to lead universities in other countries.

\section{Two EXAm PLes}

American universities were among the first to benefit from attracting an influx of foreign-born scholars, thinkers, and researchers immigrating to the United States, beginning in the late I930s but especially during and after the Second World War. When, in I965, American immigration laws changed, there was steady growth thereafter in the numbers of students-particularly from India, South Korea, and Taiwan-seeking to attend American universities, earn advanced degrees, and remain in the United States on faculties and as department chairs, deans, provosts, and presidents.

Today, presidents of the 60 American member institutions of the Association of American Universities (AAU) - the most prestigious of all American researchintensive universities-number I2 foreign-born persons among them, with representatives from Australia, China, India, and Venezuela. To provide some perspective on that number, consider that a generation earlier, in 1992, six of the same American AAU institutions had presidents who hailed from Canada, China, Germany, Iran, Norway, and Sweden.

Among the AAU presidents are two who suggest just how internationally mobile experienced presidents are and how much they are valued at least in part, it seems, for their experience in countries other than their respective native one. Jean-Lou Chameau, a Frenchman and Stanford alumnus, resigned the presidency of Cal Tech in order to lead King Abdullah University of Science \& Technology in Saudi Arabia. And when Subra Suresh, a native of India, resigned the presidency of Carnegie Mellon University to accept appointment as president of Nanyang Technological University in Singapore, he was replaced on an interim basis by Provost Farnam Jahanian, who immigrated from Iran.

A second example of the globalization of university leadership can be observed in the Times Higher Education (THE) World University Rankings for 2017 for non-American institutions (25) among the 50 highest-ranked institutions, and noting the international education and employment paths of their respective heads:

- Australian National University: born in the United States and earned degrees from the University of Arizona and Harvard University.

- École Polytechnique de Lausanne: Master's from Stanford University and on faculties of Columbia University and the University of California (UC), Berkeley.

- Hong Kong University of Science: Hong Kongborn, earned degrees from CalTech and Stanford University, and on faculty of CalTech, Yale University, and the University of California, Los Angeles (UCLA).

- Imperial College London: American-born, left presidency of Lehigh University

- Karolinska Institute: Norwegian-born and educated.

- London School of Economics: Egyptian-born, 